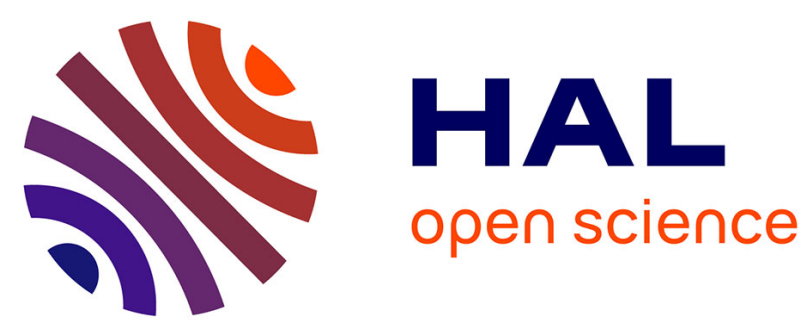

\title{
Non-human primates in HIV research: Achievements, limits and alternatives.
}

Thalía Garcia-Tellez, Nicolas Huot, Mickaël J Ploquin, Philippe Rascle, Beatrice Jacquelin, Michaela Müller-Trutwin

\section{To cite this version:}

Thalía Garcia-Tellez, Nicolas Huot, Mickaël J Ploquin, Philippe Rascle, Beatrice Jacquelin, et al.. Non-human primates in HIV research: Achievements, limits and alternatives.. Infection, Genetics and Evolution, 2016, Dec 2016, 46 (46), pp.324-332. 10.1016/j.meegid.2016.07.012 . pasteur-01419521

HAL Id: pasteur-01419521

https://hal-pasteur.archives-ouvertes.fr/pasteur-01419521

Submitted on 19 Dec 2016

HAL is a multi-disciplinary open access archive for the deposit and dissemination of scientific research documents, whether they are published or not. The documents may come from teaching and research institutions in France or abroad, or from public or private research centers.
L'archive ouverte pluridisciplinaire HAL, est destinée au dépôt et à la diffusion de documents scientifiques de niveau recherche, publiés ou non, émanant des établissements d'enseignement et de recherche français ou étrangers, des laboratoires publics ou privés.

\section{(1)(1) $\$(0)$}

Distributed under a Creative Commons Attribution - NonCommercial - ShareAlikel 4.0 
Non-humanprimates inHIVresearch:Achievements,limits and alternatives

\author{
Thalía Garcia-Tellez $^{\mathbf{a}}$, Nicolas Huot ${ }^{\mathbf{a}, \mathbf{b}}$, MickaëlJ. Ploquin $^{\mathbf{a}}$, PhilippeRascle ${ }^{\mathbf{a}}$, \\ BeatriceJacquelin ${ }^{\mathbf{a}}$, Michaela Müller-Trutwin ${ }^{\mathrm{a}, \mathrm{b}}$
}

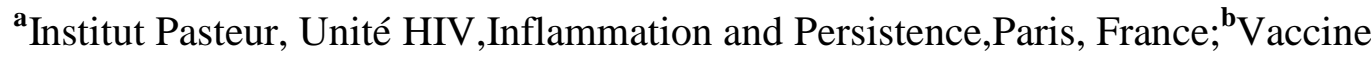
ResearchInstitute, Créteil, France.

ThaliaGARCIA-TELLEZ thalia.garcia-tellez@pasteur.fr, Nicolas HUOT nicolas.huot@ pasteur.fr,Mickael PLOQUINmickael.ploquin@pasteur.fr,Philippe RASCLE philippe.rascle@pasteur.fr,BéatriceJACQUELIN beatrice.jacquelin@pasteur.fr,Michaela MULLER-TRUTWIN michaela.muller-trutwin@pasteur.fr

Corresponding author:Michaela MULLER-TRUTWIN

michaela.muller-trutwin@pasteur.fr 


\section{Abstract}

An ideal modelforHIV-1 research is stillunavailable. However, infectionofnon-human primates (NHP), suchasmacaques, with SimianImmunodeficiencyVirus(SIV) recapitulates mostvirological, immunological andclinicalhallmarks ofHIVinfection in humans.It has become themostsuitablemodel to studythe mechanisms oftransmission and physiopathologyofHIV/AIDS. On theotherhand, natural hosts of SIV, such as Africangreen monkeys and sootymangabeys thatwhen infected do not progress to AIDS, represent an excellent model to elucidate themechanisms involved in the capacityof controllinginflammationand diseaseprogression.Theuse of NHP-SIV modelshas indeed enriched our knowledge in the fields of: i) viral transmission and viral reservoirs, ii) early immune responses, iii) host cell-virus interactionsin tissues, iv) AIDS pathogenesis, v) virulencefactors, vi) prevention and vii) drugdevelopment. Thepossibilityto control many variables duringexperimentalSIVinfection, together with the resemblancebetween SIV and HIV infections, makethe NHP model themost appropriate, so far, forHIV/AIDS research. Nonetheless,some limitations in usingthesemodels haveto be considered. Alternativemodels forHIV/AIDS research,suchas humanized mice and recombinant forms of HIV-SIV viruses (SHIV) for NHP infection, havebeen developed.The improvement ofSHIV viruses that mimic even betterthe natural historyofHIV infection and ofhumanized micethatdevelop agreater varietyof human immune cell lineages, is ongoing. Noneof thesemodels is perfect, buttheyallowcontributingto theprogress in managingor preventingHIV infection.

Keywords: HIV, SIV, AIDS, non-human primates, animal models 


\section{Highlights}

${ }_{17}^{35} \mathrm{NHPallow}$ studyingviraltransmission, immunopathology, immune response and prevention.

${ }_{17}^{35}$ Natural SIV hostshelp torevealmechanisms of HIV diseasecontrol.

${ }_{17}^{35} \mathrm{NHPmodels}$ of spontaneous or ART-inducedcontrol provideinsights forHIVcure.

${ }_{17}^{35} \mathrm{NHPmodels}$ have allowed major advancesin HIV/AIDSfield buttheyare not perfect.

${ }_{17}^{35}$ Alternativemodels(humanized mice, SHIV) areuseful forspecific research questions. 


\section{INTRODUCTION}

HIV/AIDSis stillamajorpublichealth issue. Accordingto theWorld Health Organization, HIV infection figures, even today, amongthe tenmajor leadingcauses of deathand isthe second causeof mortalityin adolescents. Sincethe first report in 1981 andthe identification ofHIVas acausativeagent in $1983^{1}$, AIDShas claimedformorethan 35 million of lives andonlyin 2015, 2.1 million of people becamenewlyinfectedwith HIV. HIV infectionis characterizedbyaslowand progressivelossof $\mathrm{CD}^{+} \mathrm{T}$ cells that, in absenceof treatment,generallyleadsto an immunosuppressive condition.Nowadays, itis admitted that chronic immune activation is the drivingforceof suchimmunodeficiency ${ }^{2}$. Undersuccessful combined antiretroviral therapy(cART), the virus is controlled up to undetectablelevelin blood, but a residual chronicinflammation persists andis associated with themorbidityand mortalityobserved in theantiretroviral-treated patients.

Despiteof thegreat advancesobtained in HIV/AIDSknowledge, there arestillkey problems to solve, in particular the lack of avaccine and acureand the absence of treatments forresolution ofHIV-induced inflammation. Animal models forHIV have alreadycontributed to answer major questions, but theyalsohaveseverallimitations. The "perfectanimalmodel" forHIV-1research isindeedstillunavailable. However,infection ofnon-human primates (NHP), such as macaques,with Simian ImmunodeficiencyVirus (SIV) leads to adiseasethat issimilar to AIDS inducedbyHIVin humans. So far, this is the mostsuitable model to studythe mechanisms of transmission and physiopathologyof thedisease.Indeed, SIV infection in macaques fulfillsnumerous conditions generally requested to constitute areliable animal model forahuman disease:

1. Thevirus causingdiseasein themodel should causethe same diseasein humans;

2. The courseof thediseaseinthe animals should resemblethat in humans;

3. The rangeof cells, tissues and organs involved should be similar in humans andin the animal;

4. Immuneresponses toinfection in the animal model should be similar to those in humans. 
These conditions arenot fulfilled byother animalmodels, such as FIVin cats or HIV-1 in humanized mice (seebelow). Here, wereview characteristics of the SIV infectionin NHP that havefavored its useas a model forHIV/AIDSresearch and summarize some of the majorpast and recentadvances inthe fieldobtained thanks to theNHPmodels(Table 1). Wewillbrieflyevoke advances in othermodels, such as humanized mice, in research towardaHIV vaccineand cure.Finally,wewill explainthe limits of NHPmodels and discuss how thesemodelscould nonetheless helpin theglobal effort to achievethe development of efficientpreventive andcure approaches.

\section{SIV MODELSAND THEIRCONTRIBUTIONSTO RESEARCH ONHIV PREVENTIONANDTREATMENT}

Human AIDSis caused bytwo types of HIV(HIV-1 and HIV-2). Theseviruses are subdivided into groups (M, N, O, and PforHIV-1;A toIfor HIV-2), subtypes,circulating recombinant forms (CRF) andunique recombinant forms (URF), HIV-1group M subtype Cbeingthe most prevalent in the world ${ }^{3,4}$.

Sincethe first casesofHIVinfection, therehas been interest inidentifying the origin of the epidemic. The first insight came to lightwhen aclose relationshipbetween HIV-2 anda virus that infectsmacaqueswas found ${ }^{5}$. This virus was called SIVmac in analogyto HIV and accordingto thespecies from which it was isolated.Thereafter, anotherphylogenetic association was discoveredbetween HIV-2 and SIVsmm, avirus that infects sooty mangabeys in West Africa ${ }^{6}$. Subsequent studies confirmed thatSIVmacand HIV-2 derived both from SIV smm ${ }^{6-9}$.

Theorigin of HIV-1 wastraced onnon-human primates, as well. Thehuman virus is closelyrelated to SIVcpz,which infects West-Central Africa chimpanzees(Pan troglodytes troglodytes $)^{7,8,10-12}$ and from which HIV-1 MandN derived ${ }^{11-16}$. On theother hand, the analysisof fecal samplesfrom Cameroongorillasrevealed the existenceofSIVgor ${ }^{17,18}$. The lattervirus is related to HIV-1 O and P. Phylogenetic analyses indicate thatchimpanzees constitute mostlikelytheoriginal reservoirand sourceof SIV gor as wellasof HIV-1O and $\mathrm{P}^{18-20}$ (Figure1).

Morethan 40 NHPspecies havebeen found to carrySIV in thewild.Noteworthy, natural carriers ofSIVareallAfrican species.In contrast,Asian monkeys, such asmacaques, are 
onlyinfected in captivity.

The first report ofAIDSin a NHPwas provided by Letvin andcolsin $1983^{21}$, soon after the discoveryofHIV. This syndromewas detected in captivemacaques (Macaca cyclopis and Macacamulatta)thatdied oflymphomas or opportunistic infections likePneumocystis carinii. The revision ofautopsyrecords and laboratorystudiesrevealed that these animals suffered of anemia, neutropenia and monocytosisbeforedecease.A lymphocyte ratio (CD4/CD8) reversion and alossof $\mathrm{T}$ cellnumbers and functionalitywereobserved aswell beforedeath.Thecauses of death included necrotizing gingivitis,Pneumocystis cariniiand cytomegalovirus infections, as wellas three atypical cases of lymphoma.

Macaques infected bySIVmacbecame themost importantanimalmodel forHIV/AIDS research. Thediseaseprogression profileduringSIVinfections in macaques depends both on the macaquespeciesand the SIVmacstrain used (Figure2). Themostfrequentlyused animals areIndianand Chinese rhesus macaquesas wellas cynomolgus macaques infected bythe SIVmac239 molecular clone ortheSIVmac251 viral isolate. Themost rapid disease progression is generallyobserved inIndianrhesus macaques infected withSIVmac239.

This macaquemodel revealed themassive $\mathrm{CD}^{+} \mathrm{T}$ celldepletion in thegut in the veryearly phaseof infection ${ }^{22-24}$. Whileitwas alreadyknown that HIV replicates inthe gut $^{25}$, the macaquemodel helped to underscorethe rapidityofthe events in this tissue (within the first $24 \mathrm{~h}$ upon infection) and to what extent the degreeofT lymphocytelossin thegut is associated with diseaseprogression.It wassubsequentlyshown that resting memoryCD ${ }^{+} \mathrm{T}$ cells werethe most frequentlyinfected cells within thegastrointestinal (GI) tract ${ }^{26,27}$. Thesecells can live fordecades andarenowconsidered asamajorreservoir forHIV-1 ${ }^{28,29}$. Experimental SIV infectionscan beperformed through the intravenousroute. Several additionalexperimental protocolshavebeen developed forinfection through therectal, vaginalororal routein order to mimicthe predominant routes oftransmission encountered in humans, i.e. sexual or mother-to-child transmission bybreast feeding ${ }^{20,22-24}$. To better resemble even morewhat is happeningduringinfectionand dissemination ofthe virus throughout thebodyin humans, protocols forrepetitivelow-dose challengeshavebeen set up as well. Thesemodelscontributetoevaluatevaccine candidatesandalreadylead to thedemonstration oftwo constructions that canconfer strongcontrol, i.e. SIV $\Delta$ nef andrhesuscytomegalovirus (CMV)-based vectors. However,the degreeof protection correlates 
inverselywith thelevel of attenuation,the least-attenuated straingivingthegreatest protection $^{33,34}$. Vaccinecandidatesbasedon CMV-vectorsgeneratevery strongandpersistentTeffectormemoryresponsesinhalfoftheanimalsleadingtoacontrolledinfec tionandaneliminationofviralreservoirs ${ }^{35}$.While it isatthemomentunclearifsuchconstructionscanbeusedasavaccine,thestudies of thesevaccine candidates have

alreadyand willcontinueto provideimportant clues about the correlates ofprotectionagainstHIV $^{36,37}$.

Themacaque/SIVmac models also allow to examinethe veryfirst immunological events after viral exposurein relation to thetransmission route ortostudythe selection mechanisms of transmitted/founder virusresultingfrom thegeneticbottleneck that occurs duringtransmission(Table 1$)^{38-42}$. It was shown forinstance in themacaquemodel, that whilein most cases the transmission is basedon the selection and persistenceof onlyone viral variant from the donor, thenumberof transmitted founder variants increases withthe viral dose in the challenge $\mathrm{e}^{31,43-45}$.

In the search foravaccineagainstHIV-1, thereis a need for ananimal model that can be infected with the humanvirus. Such amodel would help, forinstance, in thestudyof neutralizingantibodies (Nabs) againstHIV-1. Macaques aresusceptible to HIV-2 but notto HIV-1 infection. Chimpanzees constitutethe original reservoir ofHIV-1 and thereforeare naturallysusceptible to HIV-1 viruses.However,HIV-1 hadadapted to thenew human host, most likelybycircumventing restriction factors, amongother reasons. Therefore, the results obtained from HIV-1 infection in theseprimates havebeen non conclusive. Some groups havereported thedevelopment of AIDS inthis model, ${ }^{46-49}$ characterized bymarked depletion of CD4+T cells, sustained viremia, severeCD4:CD8 inversion and increased T cellapoptosis. Others haveobservedanimals that do notor onlyslowlyprogress to AIDS, maintainingtheirnormalCD4+T cellcounts anddisplayingundetectableviremia ${ }^{50}$. Thescientificlimitations of themodel, together with thenewguidelines for theuse of chimpanzees in biomedical research, leaded to theinterruptionofits use for $\mathrm{HIV}^{51}$. Infection ofmacaques with HIV-1 hasalso revealed to bechallenging.Indeed,HIV-1faces in macaques theexistenceof cellular proteins thatrestrict the replicationofthe human virus, such as TRIM5 $\square^{52}$,APOBEC3G and Tetherin ${ }^{53}$. This makes it difficultto infect macaques or their $\mathrm{CD}^{+}{ }^{+} \mathrm{T}$ cells byHIV-1 invivoand in vitro, but allowed to contributeto 
the discoveryandextensive characterization ofrestrictionfactors (Table 1).Several TRIM5 $\square$ alleles havebeen identified and characterized in monkeys.It has been clearly shown that theviral replication differs depending on the TRIM5 $\square$ allele present in the simian host $\mathrm{h}^{5,55}$. Theonlymacaquesusceptible tobeinfected byHIV-1 is thepig-tailed macaque(Macaca nemestrina). This occurs as aresultof a2-nucleotide deletion in the 5'end ofTRIM5 $\alpha$ transcript, which impairs the action of this $\mathrm{RF}^{16}$. However,the viral replication is not efficient and thereis no diseaseprogression.

A recombinant virus hasbeen engineered, which consistsof aHIV-1 backbonewhere target sites ofrestriction factors were replaced bythe correspondingSIVmacsequences ${ }^{56}$. Whilethis virus inducespersistent viremia, diseaseprogression is onlyobserved after in vivo depletion of CD8+T cells in acute infection.This modified model allows the studyof some virus-host interactions, butneeds further developmentforits applicationin HIV research. Another attemptto circumvent the lack of a macaquemodel forHIV-1 consists in the construction of othertypes of recombinant viruses of HIV and SIV, calledSHIV ${ }^{57}$. These havebeen used sincemany yearsto overcome thelack of ananimal model byconstructing forinstanceSIVmac viruses coding forHIV-1 Envinstead of SIVmacEnv. Suchmacaque/SHIVmodels were essential forprovidingthe proof ofconcept that antibodiesalone can protect againstinfection bytaking advantageof thepossibilitytopassivelytransfer the antibodies and challengetheanimals experimentally ${ }^{58}$ (Table 1).However,thesetypesofapproachesarechallenged bythelargediversityof theenvelopeglycoprotein, theirglycan shields and bythehighplasma titers ofNAbsneededforprotection.Lately,theimprovement ofbroadlyneutralizing monoclonalantibodies(bNAbs)allowedtoenhancetheirneutralizationpotencyandtoprotect, $\mathrm{f}$ orinstance,SHIV-challengedmacaqueswithmuchlower NAbsconcentrations ${ }^{59}$.This newgenerationofverybroadandpotentAbsmighthaveapotentialnotonlyas preexposureblockingagentsbutalsoinviewofacureor remissionofHIV.ThetreatmentwiththoseAbsresultedindeedin controlofvïremiaandreducedproviralDNAinbloodandtissues ${ }^{60,61}$. Veryearly on,SIVs thatencode for HIV-1 Pol have also beenengineered.Indeed, SIVmac virusesarenot susceptible to somedrugs used againstHIV-1, such as non-nucleoside 
reversetranscriptaseinhibitors (NNRTIs), fusion inhibitors and someintegraseinhibitors. The engineeringof SHIV sexpressingthe HIV-1 Pol protein makes them susceptible to such antiretrovirals.Theycontributed to thedevelopment oftherapeutic approaches.As anexample, NHPinfection models havedemonstrated the effectiveness of subcutaneous,gel,and oral formulations oftenofovir (PMPA)in preventingtransmission ofSIV or SHIV

viruses, even when applied several hours after viral challenge ${ }^{62}$. Such in vivoactivityof tenofovir madeitapromisingagentforpreventionof HIV-1 infection.

Most SHIV viruses, however, do not reproduce all characteristics ofHIV-1infection in humans. The firstgeneration of SHIVwas composed of X4 virusesand thereforedisplayed adistinct cellulartropismthan primaryHIVin earlyinfection.CD8+T celldepletion in monkeys isstilloften needed fordisease progressionto AIDS.Nevertheless, SHIVmodels have allowed overcomingspecific hurdlesand cannot be missedso farforpre-clinical trials ofvaccine and drug candidates ${ }^{63-67}$.

As wehave recapitulated, SIV infection in NHP constitutes agood model,in manyaspects, forHIVresearch.It is, however, not perfect. Onecannot ignorethat SIVand HIV are close but different viruses, which can lead to differencesin certain aspects oftheir interactions with thehost or susceptibilityto drugsand vaccinecandidates.

\section{MODELSFORSPONTANEOUSSIV CONTROL}

Themajorityof theindividualsinfected byHIVprogresses to AIDSwithin7 to 10yearsin the absenceof cART. There exist, however,afewindividuals $(<0.2 \%)$ known as HIV- controllers who spontaneouslyandefficientlycontrol viral replication. Thedeep characterization oftheseindividuals and the factors that areinvolved in thecontrol of the infection havebeen thefocus of manyresearches ${ }^{68,69}$. Multiple causes aresuspected, and arenot mutuallyexclusive. In particular thegenetic backgroundof theindividuals enriched in MHCalleles such asB27 and/or B57, strongCD8+T cell responses, reduced susceptibilityof CD4+Tcells to HIV infectionandearlycontrol ofviral replicationare likelyinvolved ${ }^{70,71}$. All distinctprofiles of diseaseprogression in humans are recapitulated bymacaquesafter SIVmacinfection, includingtheoccurrenceofa spontaneously controlled infection in aminorityof macaques thatcan also be related to aspecific MHC background $^{51,97}$. Thediseaseprogressionratedepends both on the virus and host species 
(Figure2), as wellason individual host features, as in humans. Studiesin the macaque 
modelallow deciphering,onebyone, the role of eachviralgenein vivo byinfecting macaques withgeneticallyengineered SIVmacclonescontainingdefectiveorlacked accessorygenes.This ishow it was discovered that Nefis essential for high viral replication in vivo, whilein vitro, Nef was dispensable ${ }^{72}$. Mutations inNefindeed are associated with attenuatedHIV-1 infection in humans.

Theroleof MHCalleles(Mamu alleles inrhesusmacaque) has been extensivelystudied in the spontaneous controlin macaques. Some Матиalleles (e.gМати- $A * 01^{73}$ )are associated with abetter containment of viral replication while others arelinked to a faster diseaseprogression ${ }^{74}$. Furthermore, thecombination ofMamu alleles and KIRreceptors in NK cells increases thecomplexityof theresponse ${ }^{75,76}$, as showed for example in an epistatic analysisof KIR3DL05, KIR3DS05, and KIR3DL10 in association withМати- B*012 that contributetoelevate theviral load inrhesusmacaques ${ }^{76}$.

TheNHPmodels allow investigators to address not onlythe veryearlyevents that follow SIVexposure, but also tostudytheseevents in tissues, such as lymphoid tissues, genital tract, lung, liver, intestine, and central nervoussystem $(\mathrm{CNS})^{77}$. Latent reservoirs of HIV arelocated throughout thebodyand persist during infection even in presencehighly efficientcART. NHPmodels allow to studythe establishment ofthese reservoirs intissues, which occurs in thefirsthours and days following infection ${ }^{78-80}$. Advances in our understandingof the roleof thedifferent immunecellpopulationsas viral target cells, have been provided byexperiments in which thesepopulations aredepleted in NHP models. Depletion of $\mathrm{CD}^{+}{ }^{+} \mathrm{T}$-cells in macaques priorto SIVinfection wasassociated with higher viral load, massive activation and infection ofmacrophages andmicrogliathat become the predominant infected cells ${ }^{81}$. TheSIVmac-infectedmacaque modelwas usedas a proof-ofconcept to demonstratethatCD8+cells participate in the control of infection,usingin vivo CD8+T celldepletion(Table 1) ${ }^{82-84}$. Additionally,this model allowed todemonstrate the presenceof aCTL response as soon as 7 daysp.i.,and helped to understand how quickly HIV/SIV evades thiscellular response through theacquisition ofmutationsveryearlyon in acute infection ${ }^{85}$. Themacaquemodelalso provided the concept that $\mathrm{CD} 8+\mathrm{T}$ cell responsesarrive "too little" and"too late"into vaginal mucosato control viral disseminationand that the "window ofopportunity"to prevent infection is veryshort ${ }^{86,87}$. Furthermore, depletion of NK cells resulted in modest changes in plasmaviral load but ina 
significantincreasein the gut ${ }^{88,89}$. However, notoolsexistso far to specificallydeplete NK cells and CD8+T cells. Noteworthy, celldepletion inducehomeostaticproliferations of other cells, this side effectin addition to others need to be taken into consideration in the interpretationoftheresults.

\section{MODELSFOR DISEASE CONTROL}

About 40 distinct African NHParenatural hosts of SIV.Onlyina few species though, studies could be conducted to evaluate thenaturalhistoryof SIV infectionand its outcome in these animals. Studies based on non-invasive techniques haveshown that SIVcpz infection in wild chimpanzees reduces their lifespan, when compared to non-infected animals in the same habitat $^{16,90}$. One caseof AIDSrelated symptomswas also reportedin anaturallyinfected CentralAfricanchimpanzee, which presented lymphopenia, weight lossand opportunisticinfections 7years after SIV positive screening.Efforts should be madetobetter characterizethe pathogenicityof SIV in natural hostsand to find out whetherSIVinfection also plays a roleinapepopulation decline ${ }^{91}$. Other studies in semi-freemandrills infected bySIVmnd in their natural habitat revealed, in contrast, astrongprotection against AIDS. Similarly, otherAfrican NHP, such as African Green Monkeys(AGM) and Sooty mangabeys (SM) revealed to be resistant to $\operatorname{AIDS}^{92}$. Thelatterservetodayas model to studythe control of thedisease, in particular SM and AGM, and arecalled the "natural hosts"models. Cross-species transmissions demonstrated that thesameSIVstrain cancause opposite outcomesofinfection, dependingof thehost species (Figure3). On the otherhand, not all SIV strains induceAIDS in macaques, someSIV viruses beingeasily controlled in the animals, while others not. This demonstrates that theoutcome ofthe infection depends ona combination ofboth viral and host determinants.

Natural hosts ofSIV have been used to better understand themechanisms responsibleofdiseaseprogressionin HIVinfection ${ }^{92,93}$. Themost strikingdifferencebetween non- pathogenicSIV and pathogenicHIV-1/SIVmacinfections is the lack ofchronicimmune activation. Paradoxically,natural hosts of SIV exhibit high titers of virus in plasma,but theydo notdisplaychronic activation ofthe adaptive and innateimmune system ${ }^{94,95}$. This featureresembles the 'viremicnon-progressors', veryrarehuman individualswho display elevated viremiabut maintain CD4 T+cellcountsand avoid diseaseprogression for 
years $^{96}$. Extensivestudiesareongoingin order to elucidate themechanisms involved in the capacityfor controllinginflammation and diseaseprogression. Some non-mutually exclusivehypotheses are listed below ${ }^{97}$ :

${ }_{17}^{35}$ Intactmucosa barrier, thereby, lack of microbial translocation and lack ofmicrobial products thatwould drive the continuous stimulation of theimmune system ${ }^{98}$. Experimentallymimickingmicrobial translocation in thesenonpathogenicmodels provided evidenceof thelink between this phenomenon and immune activation. LPSadministration in AGMs leaded indeed to elevatedT cell activation levels ${ }^{99}$. However, it isunlikelythat this isthe onlyevent involved in the deleterious chronic inflammation as ithas been shown that infection of macaques with amutated virus stillleads to AIDS without acute loss of CD4+Tcells and microbial translocation ${ }^{100}$.

${ }_{17}^{35}$ Ancient infection that ledto an adaptation of thehost's immune response responsible fordifferences inthe intensityornatureofSIV sensing. The capacityto produceIFN-Iis normalin natural hosts, but othersensingpathways haveonly poorlybeen explored innatural hosts so far $^{101,102}$.

${ }_{17}^{35}$ The abilityof the Nef protein toblock the activation ofinfected Tcells by downregulation of $\mathrm{CD} 3^{103}$.

${ }_{17}^{35}$ Natural hosts show low levels of CCR5 surface expressionon CD4 +T cellsand apparent protection ofcentral memoryT cellsfrom SIV infection ${ }^{104-106}$

${ }_{17}^{35}$ Controlled viralreplication in secondarylymphoid organs ${ }^{107}$. Onehallmark of SIV infection in natural hostsis thelow viral burden in lymph nodes in the chronic phaseof infection in contrast to othertissues ${ }^{108-112}$. This constitutes oneof the majordifferences in lymph nodes of AGMs and SMs. Furthermore, lymphnodes in thesenatural hosts are characterized by:(i)lack of lymphadenopathyand thus no extensivesequestration oflymphocytes in AGMLNs, (ii) no orless folliculardendritic celldeposition ofvirus in AGM and SM compared to SIVmacinfections 110,112,113; (iii) more rapid control of interferon-stimulated genes (ISGs)inLNs as compared to blood andgut ${ }^{101,109-111}$. The control of viral replication and immune activation in lymph nodesprevents fibrosis and maintains normal immune 
function ${ }^{108,114,115}$ in this organ which is essential for theinduction and shapingof adaptiveimmune responses.Maintenanceof normal immune functions mightlead to a better control of other infections in the host (i.e. CMV, virome)that otherwise could alsocontributeto immune activation.

${ }_{17}^{35}$ Depletion of CD4+T cells through apoptosis leadingto homeostaticproliferation of T cells ${ }^{116,117}$

\section{SMALLANIMALMODELSFOR HIV RESEARCH}

Besides NHPs, other animalmodels havebeen usedforthe studyof HIV-1.In the past,felineimmunodeficiencyvirus (FIV) infection in cats servedas a model ofnaturallyoccurringimmunodeficiency.DuringFIV infection, CD4+T cells aredepleted and a chronic inflammatorystate is established,such asithappens during HIV/SIVinfection ${ }^{118}$. TheFIVmodel has alsobeenuseful in thepastto test some antiretroviral drugs ${ }^{119}$. Nowadays, however, thismodelisgenerallynot usedanymoreforHIVresearch since some importantfeatures of theinfection areclearlydifferent.Forexample, FIV is able to infect $\mathrm{CD} 8+\mathrm{T}$ cells andBcells in addition to $\mathrm{CD} 4+\mathrm{T}$ cells andmacrophages, dueto its affinityforCD134 asareceptor. Thus,FIVestablishes different viral reservoirs in comparison with thehuman orprimate infection byHIV/SIV.

Other attempts forstudyingHIV-1 infection in small animals such asrats,miceor rabbits wereperformed withoutsuccess.Indeed, rodent cells arerefractoryto HIVinfection. This could not be circumvented bytheexpression ofthe human viralreceptor on the cellsurface. When the murine cells wereengineered forallowing HIV to enter, thevirus encountered additional problems to effectivelyreplicate, mostlikelydueto restriction factors, among others.

Thedevelopment of humanized mice arose thepossibilitytoinfect them with HIV-1 and answer some specificresearch questions. Examples of humanized mice used inHIV research comprise, interalia, SCID-hu, SCID-hu-PBL,NOD-SCID, Hu-HSCand BLT mice $67,68,120-122$. Humanized micehavebeen used to studypunctual aspectsofHIV-1 infection, such as Tcell exhaustion ${ }^{123}$, mucosal immunity ${ }^{120,124,125}$, viral latency, antiretroviral drug efficacies and infection ofmacrophages ${ }^{124,126,127}$, amongothers(Table 
2).Humanized micehave alreadycontributed to theknowledgeof specificaspects ofHIV infection. However, theirdevelopment requires complexsurgical engineering.Moreover, theyneed to begenerateddenovo foreach experiment, beingtailored accordingto the immunological requirements of the research, which increases the cost oftheir establishment and maintenance.In addition, there existanatomical differences,for example, at thelevel oflymphoid organsthatarenot fullydeveloped andalack of several human immune cell lineages, in particular related toinnateimmune responses. Ofnote, the field is evolvingfast and much effort is put on the improvement of humanized micemodels ${ }^{121}$.

\section{LIMITATIONS, PERSPECTIVESANDCONCLUSIONS}

Despitethe numerous advantages that NHP represent, it is important nottoforget that choosingtheright modelfor each research question is an essential point. Macaquemodels oftransmission were establishedveryearlyonasmodels forHIV ${ }^{128}$. Animal modelsoffer the possibilityto controlthe viral strain, viral doseand infection route.However,while it is welladmittedthat rectal SIV infection mimics whatis happeningin humans, vaginal infections aremoredifficulttomodelize as menstrual cycle variations impact thethickness ofthe epithelium and theefficacyof infection ${ }^{32,129}$. Progesteroneis used tocontrol the cycle but to what extent this impacts the relevanceof the studies is stillunder debate. Also, humans areinfected through biological fluids that do notonlycontain freevirus, but also infectedcells andother components, suchasinflammatorycytokines.Studies are ongoingto evaluate if therearedifferences dependingon the composition of the inoculum $^{130,131}$.

Natural transmission ofSIVin African NHPs ispredominantlyhorizontal and thought to occurthrough sexual contacts or bitewounds.In contrast to HIV infections, vertical transmission ofSIV is extremelyrare.Theexpression ofthe co-receptor CCR5 on $\mathrm{CD}^{+} \mathrm{T}$ cells in AGMs is low in infants and dramaticallyincreases in adults ${ }^{132}$. Susceptibilityto infection through the vaginal and rectal routewas linked to the availabilityofmemory $\mathrm{CCR} 5^{+} \mathrm{CD} 4^{+} \mathrm{T}$ cells in thetargeted mucosa and ithas been suggested that thelow rate of vertical SIV infection isassociated with the few target cellavailabilityin newborns and infants ${ }^{133,134}$. Thus, whileHIV and SIV infectionsaredistinct in the frequencyof motherto 
child transmission, NHPmodels can beusedtobetter understand the underlying mechanismof this difference $\mathrm{e}^{133,135,136}$.

Onceinfection takes place at mucosal sites, the virus crosses the epithelial barrier, establishes a first poolofinfected cells (foci)anddisseminates thereafter indraininglymph nodes $(\mathrm{LNs})^{30}$.It is still underdebatewhich cells arethe first targets ofthevirus. It has been suggested that CD4+CCR5+T cells aretheprimarytargets ofinfection in mucosa $24,26,27,137,138$. Dendritic cells (DCs)mightalsoplayarolein theprocessofviral dissemination.Theuse of macaquemodels permitted toanalyzetheir rolein virus disseminationduringthefirst hours and daysin vivo ${ }^{139}$. Nonetheless, theevents leadingto the establishment of infection arestillnot fullyelucidated.

Repeated low-doseviralchallenges might provideabenefit for the evaluation of vaccine candidates or theunderstandingofthe establishment of viral reservoirs. Thelow number of animals for ethicaland economicreasonsrendersinterpretation of theresultshowever sometimes difficult. Taken this into account,technicalimprovements are beingmade. For instance, novel techniques, such as in vivo imaging, arehighlypromising ${ }^{77}$.It isimportant to mention that not onlythe numberof specimensallowed foreachresearch is often limited, but thetools arelimited as well. Thus, there arestillmarkers for which no monoclonal antibodyexistsin monkeys. This is the casefor example formost of the KIRs. NHParetheclosest animal model forHIV/AIDS research, but an ideal modelforHIV-1 is stillnot available. SIV and HIV are close but distinct viruses, which causedifferences in certain aspectsoftheirinteractions with the host, vaccinesand drugs. To overcome these potential discrepancies between SIVand HIV,recombinant viruses, includingSHIVs, have beengenerated. SHIVs havebeen and still areparticularlyuseful in thestudyof humoral responses, vaccinecandidates and antiretroviral drugs ${ }^{67}$.In thefuture, itwould be useful howeverto disposeofSHIV viruses that mimicevenbetter thenatural historyof HIV infection. Thedevelopment of newgenerations ofSHIV strains is alreadyongoing. Inconclusion, non-human primates infected bySIV represent a model withnumerous advantagesforthe studyofHIV infection.Its close resemblanceto HIVinfection in humans probablymakesitthe best or at least themostdeeplycharacterized animal model forahuman disease. NHP-SIV models have allowedthe studyof: i) viraltransmission,ii) 
earlyimmune responses, iii) host cell-virus interactions in tissues, iv) preventionand v) drugdevelopment(Table3).

Despiteof allthe caveats noted and the potential difficultyin translatingthefindings from primates to humans, thesemodels can beand havebeen highlyinstructivein establishing certain basicprinciples that would havebeen difficultor impossible to determineby experimentation in humans forsafetyreasons.

Ofnote, the suitabilityofeach model depends on the study's specific question, the available toolsand appropriateinterpretation of the results. Nonetheless, ifused correctly, it constitutes an essential model, in manyaspects, for HIV researchuntil a vaccine and therapyfor HIVcureorHIV remissionarediscovered. 
Table 1. Examples of major contributions of NHP models to HIV/AIDS research

(] Discoveryof initial founder populations of infected cells (foci) ${ }^{30}$

๑ CD8+T cellresponse: «too little, too late»to clear infection ${ }^{86}$

(1) Short window ofopportunityto prevent infection ${ }^{38}$

(] CD8+T cells :impact onviralset-point ${ }^{74,140}$

(1) Proofof concept that Nab can protect againstinfection ${ }^{141}$

(]) Nef viral protein:necessaryforhigh viral load invivo ${ }^{72}$

0 RestingmemoryT cells: main target of thevirusin lymphoid tissues ${ }^{24,27}$

4 Rapid and dramatic depletion of CD4+T cells ingut ${ }^{22,27}$

(1) Traffickingof Treg, PDC, NK cells to thegut ${ }^{142-144}$

(u) Loss of Tcm associatedwith diseaseprogression ${ }^{24,145}$

Events in acute infection determinediseaseprogression ${ }^{70}$

(1) TRIM5aalleles restrict viral replication invivo ${ }^{86}$

(4) Analyses of thevirome and microbiome in tissues ${ }^{31-134}$

In vivo imagingof $\mathrm{SIV}^{77}$ 


\begin{tabular}{|c|c|c|c|}
\hline Model & Characteristics & Examples of utility & Drawbacks \\
\hline \multicolumn{4}{|l|}{ Alternative viruses } \\
\hline \multicolumn{4}{|l|}{ Alternativehosts } \\
\hline SCID-hu ${ }^{150}$ & $\begin{array}{l}\text { Human hematopoietic progenitor } \\
\text { stemcells that maturemainlyinto } \\
\text { T cells. }\end{array}$ & $\begin{array}{l}\text { Studyof CD4+Tcellloss } \\
\text { Test of antiretroviral drugs }\end{array}$ & $\begin{array}{l}\text { Absenceof innate immunity. } \\
\text { Not suitableto studyviral } \\
\text { transmission. }\end{array}$ \\
\hline $\begin{array}{l}\text { BLT }^{152} \\
\text { (Bone-liver-thymus) }\end{array}$ & $\begin{array}{l}\text { Human T andBlymphocytes, } \\
\text { monocytes, macrophages, NK and } \\
\text { dendritic cells. } \\
\text { Develops mucosal immunity, } \\
\text { includingGALT. }\end{array}$ & $\begin{array}{l}\text { Antiretroviral treatment tests } \\
\text { Studies of viral transmission and } \\
\text { replication in mucosa }\end{array}$ & $\begin{array}{l}\text { Defect in class-switched } \\
\text { antibodyproduction. } \\
\text { Predominanceof pre-matureB } \\
\text { cells }{ }^{154}\end{array}$ \\
\hline
\end{tabular}


Table 3. NHPuse towards a cureforHIV: advantagesand applications

\begin{tabular}{|c|c|c|}
\hline Aim & AdvantageofNHPuse & Examples ofstrategies studied \\
\hline $\begin{array}{l}\text { Pharmacological viral } \\
\text { suppressionanddiminution } \\
\text { ofviral reservoirs }\end{array}$ & $\begin{array}{l}\text { Control of viral strain } \\
\text { Control of viral dose andnatureof inoculum } \\
\text { Control of route of administrationand timing }\end{array}$ & $\begin{array}{l}\text { Diffusion of antiretroviral drugs in tissues } \\
\text { Veryearlytreatment initiation } \\
\text { Treatment withIFN- } \\
\square \text { Treatment with bNabs }\end{array}$ \\
\hline $\begin{array}{l}\text { Restaurationandenhancing } \\
\text { ofimmune response } \mathrm{s}^{85,86}\end{array}$ & $\begin{array}{l}\text { Control of duration, typeand combination of } \\
\text { antiretrovirals }\end{array}$ & $\begin{array}{l}\text { Treatment withInterleukins (IL-7,IL-15,IL-21) } \\
\text { Treatment with TLR7agonists } \\
\text { Treatment with anti PD-1 }\end{array}$ \\
\hline $\begin{array}{l}\text { Purgelatent HIV- } \\
\text { reservoir }^{159-163}\end{array}$ & $\begin{array}{l}\text { Analyses of immune responses in tissues } \\
\text { includingimmediatelyafterinfection } \\
\text { Intervention in the earlystageof primary } \\
\text { infection } \\
\text { Administration ofpotentiallyriskysubstances }\end{array}$ & $\begin{array}{l}\text { Administration ofinhibitors of chromatin- } \\
\text { remodelingmolecules (SAHA-inhibitors) } \\
\text { Gene editing } \\
\text { Nanoparticles }\end{array}$ \\
\hline
\end{tabular}




\section{FUNDING}

TGTis a fellow from the PasteurParis University International $\mathrm{PhD}$ program and supported bytheInstitutCarnot PasteurMaladiesInfectieuses. NH and MJPwere, respectively, supported byfellowships from theVaccine ResearchInstitute(VRI) and Sidaction. Wethank the French AgencyforAIDSResearch(ANRS), theInstitut Pasteur, Sidaction, the«Investissements d'Avenir"programmanaged bythe ANRgrant agreement $\mathrm{N}^{\circ}$ ANR-10LABX-77 and ANR-11-INBS-0008, as wellasL'Oréal in partnership with UNESCO fortheirsupport.The fundingsources had no influenceon our studies orin the writingof this report.

\section{ACKNOWLEDGMENTS}

Wewould liketo thankLiviaPedroza-Martinsand PierreRoques forcontributingwith visual material. Furthermore, weacknowledgethestate-of-the-art NationalCenter for Infectious DiseaseModels andInnovativeTherapies (IDMIT).

\section{CONFLICT OFINTERESTS}

The authors declarenot to have anyconflict of interests. 
1. Barré-Sinoussi, F.etal.Isolationof aT-lymphotropic retrovirus fromapatientatrisk for acquired immunedeficiencysyndrome(AIDS).1983.Rev. Investig. ClínicaOrgano Hosp. EnfermedadesNutr.56,126-129(2004).

2. Paiardini, M.\&Müller-Trutwin, M. HIV-associatedchronic immuneactivation.Immunol. Rev. 254,78-101(2013).

3. Peeters,M.,Jung, M. \&Ayouba, A. Theoriginandmolecular epidemiologyof HIV.Expert Rev. Anti Infect.Ther.11,885-896(2013).

4. Hemelaar, J. Theoriginanddiversityofthe HIV-1pandemic.TrendsMol. Med.18,182-192 (2012).

5. Chakrabarti,L. etal.Sequence ofsimianimmunodeficiencyvirus frommacaqueandits relationshipto otherhumanandsimianretroviruses.Nature328,543-547(1987).

6. Hirsch, V. M.,Olmsted,R.A., Murphey-Corb,M.,Purcell, R.H. \&Johnson,P.R. AnAfrican primatelentivirus (SIVsm)closelyrelatedtoHIV-2. Nature339,389-392(1989).

7. Gao, F.etal. Originof HIV-1in thechimpanzeePantroglodytestroglodytes.Nature397, 436-441(1999).

8. Bailes, E.etal. Hybridoriginof SIVin chimpanzees. Science300,1713(2003).

9. Chen, Z. etal. Geneticcharacterizationof newWestAfricansimianimmunodeficiencyvirus SIVsm:geographicclusteringof household-derived SIV strainswith human immunodeficiencyvirustype2subtypesandgeneticallydiversevirusesfroma single feral sootymangabey troop.J. Virol. 70,3617-3627(1996).

10. Peeters,M.etal. Isolationandpartial characterizationof an HIV-relatedvirusoccurring naturallyin chimpanzees inGabon.AIDS3,625-630(1989).

11. Simon,F. etal. Identificationof anewhumanimmunodeficiencyvirustype1distinctfrom groupMandgroupO.Nat.Med.4,1032-1037(1998). 
12. Corbet,S. etal. envSequencesof SimianImmunodeficiencyVirusesfromChimpanzees in CameroonAre StronglyRelatedto ThoseofHumanImmunodeficiencyVirus GroupN from the SameGeographicArea.J. Virol. 74,529-534(2000).

13. Müller-Trutwin,M. C.etal. SIVcpzfromanaturallyinfectedCameroonianchimpanzee: biologicalandgenetic comparisonwith HIV-1N. J.Med. Primatol. 29,166-172(2000).

14. Nerrienet,E.et al. SimianImmunodeficiencyVirus Infectionin Wild-CaughtChimpanzees fromCameroon.J. Virol.79,1312-1319(2005).

15. Keele, B. F. etal. ChimpanzeereservoirsofpandemicandnonpandemicHIV-1.Science313, 523-526(2006).

16. Peeters,M.\&Delaporte,E.Simianretroviruses in Africanapes.Clin. Microbiol.Infect. Off. Publ.Eur.Soc. Clin. Microbiol. Infect. Dis. 18,514-520(2012).

17. VanHeuverswyn,F.etal. Humanimmunodeficiencyviruses:SIVinfectionin wildgorillas. Nature444,164(2006).

18. Plantier,J.-C. etal.A newhumanimmunodeficiencyvirus derivedfromgorillas.Nat. Med. $15,871-872(2009)$.

19. Takehisa,J. etal.Originandbiology ofsimianimmunodeficiencyvirus inwild-livingwestern gorillas. J. Virol.83, 1635-1648(2009).

20. D'arc,M.etal. Originof theHIV-1groupOepidemicinwestern lowlandgorillas. Proc. Natl. Acad. Sci. U. S. A.112, E1343-1352(2015).

21. Letvin, N.L.etal. Acquiredimmunodeficiencysyndromeinacolonyofmacaquemonkeys. Proc. Natl. Acad.Sci.U. S.A. 80,2718-2722(1983).

22. Veazey,R.S. etal. Gastrointestinaltractas amajor site ofCD4+Tcelldepletionandviral replicationin SIV infection.Science280,427-431(1998). 
23. Kewenig, S. etal. Rapidmucosal CD4(+)T-celldepletionandenteropathyin simian immunodeficiencyvirus-infected rhesusmacaques.Gastroenterology116,1115-1123 (1999).

24. Mattapallil,J.J. etal.MassiveinfectionandlossofmemoryCD4+Tcellsinmultiple tissues duringacuteSIVinfection.Nature434,1093-1097(2005).

25. Schneider,T.etal.LossofCD4Tlymphocytesin patientsinfected with human immunodeficiencyvirustype1ismorepronounced intheduodenalmucosa thanin the peripheral blood. BerlinDiarrhea/WastingSyndromeStudyGroup.Gut37,524-529(1995).

26. Brenchley,J.M.etal. CD4+TCellDepletionduringallStagesof HIVDiseaseOccurs Predominantlyin theGastrointestinal Tract.J. Exp.Med.200,749-759(2004).

27. Li, Q.etal.PeakSIVreplicationin restingmemoryCD4+Tcells depletesgutlamina propria CD4+Tcells.Nature434,1148-1152(2005).

28. Schmitz, J.E.etal.MemoryCD4+TLymphocytesin theGastrointestinal TractArea Major Sourceof Cell-AssociatedSimianImmunodeficiencyVirus in Chronic Nonpathogenic Infection of AfricanGreen Monkeys.J. Virol. 86,11380-11385(2012).

29. Chomont,N. etal.HIVreservoirsize andpersistencearedriven byTcellsurvivaland homeostaticproliferation. Nat. Med.15,893-900(2009).

30. Haase,A.T.TargetingearlyinfectiontopreventHIV-1mucosal transmission.Nature464, 217-223(2010).

31. Fennessey, C.M. \&Keele,B. F.UsingNonhumanPrimates toModel HIVTransmission.Curr. Opin. HIVAIDS 8,280-287(2013).

32. Evans,D. T.\&Silvestri, G.Non-HumanPrimateModels inAIDS Research.Curr. Opin. HIVAIDS 8,255-261(2013). 
33. Johnson, R.P.\&Desrosiers, R.C.Protective immunityinduced byliveattenuatedsimian immunodeficiencyvirus.Curr. Opin. Immunol.10, 436-443(1998).

34. Koff,W. C.etal. HIVvaccinedesign:insightsfromliveattenuatedSIVvaccines.Nat. Immunol. 7,19-23(2006).

35. Hansen, S.G. etal. Immuneclearanceof highlypathogenicSIV infection.Nature502,100104(2013).

36. Daniel,M.D., Kirchhoff, F.,Czajak, S. C., Sehgal, P.K. \&Desrosiers,R.C. Protectiveeffectsof a liveattenuatedSIVvaccinewitha deletioninthenefgene.Science258,1938-1941(1992).

37. Billingsley, J.M.etal. Characterization of CD8+TCellDifferentiation followingSIV $\Delta$ nef Vaccinationby TranscriptionFactorExpressionProfiling.PLoSPathog.11,(2015).

38. Sodora,D.L., Gettie, A.,Miller,C. J. \&Marx,P. A.Vaginal transmissionof SIV:assessing infectivityandhormonal influencesinmacaques inoculated withcell-freeandcell-associated viral stocks.AIDSRes. Hum.Retroviruses 14 Suppl 1, S119-123(1998).

39. Milush, J. M.etal. Rapiddisseminationof SIVfollowingoralinoculation.AIDS Lond. Engl.18, 2371-2380(2004).

40. Keele, B. F. etal. Low-doserectal inoculationof rhesusmacaquesbySIVsmE660 or SIVmac251recapitulateshumanmucosal infectionbyHIV-1. J. Exp.Med. 206, 1117-1134 (2009).

41. Tsai, L.,Tasovski, I.,Leda, A. R., Chin, M.P.\&Cheng-Mayer,C. Thenumberandgenetic relatedness oftransmitted/foundervirus impactclinical outcomeinvaginal R5 SHIVSF162P3Ninfection.Retrovirology11,22(2014).

42. Tully,D. C. etal. Differences in the SelectionBottleneckbetween Modesof Sexual TransmissionInfluencetheGeneticCompositionoftheHIV-1FounderVirus.PLoSPathog. 12,e1005619(2016). 
43. Ma, Z.-M. etal. SIVmac251Is Inefficiently TransmittedtoRhesusMacaquesbyPenile Inoculationwith aSingle SIVenvVariantFoundin Ramp-upPhasePlasma. AIDSRes. Hum. Retroviruses27,1259-1269(2011).

44. Keele, B. F.\&Estes,J.D. Barrierstomucosal transmissionofimmunodeficiencyviruses. Blood118,839-846(2011).

45. Gambhira, R.etal.Transmitted/FounderSimianImmunodeficiencyVirusEnvelope SequencesinVesicular Stomatitis andSemliki ForestVirus Vector Immunized Rhesus Macaques.PLoSONE9,(2014).

46. Novembre, F. J.etal. Developmentof AIDSin a chimpanzeeinfected with human immunodeficiencyvirustype 1.J. Virol. 71,4086-4091(1997).

47. Davis, I. C., Girard,M.\&Fultz, P. N.Lossof CD4+Tcells in humanimmunodeficiency virus type1infectedchimpanzeesis associatedwith increased lymphocyteapoptosis.J. Virol. 72, 4623-4632(1998).

48. O'Neil, S.P.etal. Progressiveinfectionin a subsetofHIV-1-positivechimpanzees.J. Infect. Dis.182,1051-1062(2000).

49. Ferrari, G. etal. Theimpactof HIV-1infectiononphenotypicandfunctional parametersof cellularimmunityin chimpanzees.AIDSRes. Hum.Retroviruses 9,647-656(1993).

50. Juompan,L. Y.etal.Analysis ofthe immuneresponses in chimpanzeesinfectedwith HIV type1isolates.AIDSRes. Hum. Retroviruses24, 573-586(2008).

51. InstituteofMedicine(US)andNational ResearchCouncil (US) CommitteeontheUseof Chimpanzees inBiomedical andBehavioralResearch.ChimpanzeesinBiomedical and Behavioral Research:Assessingthe Necessity. (National AcademiesPress (US), 2011).

52. Stremlau,M.etal.ThecytoplasmicbodycomponentTRIM5alpha restrictsHIV-1infectionin OldWorld monkeys.Nature427,848-853(2004). 
53. Misra, A.,Thippeshappa, R.\& Kimata, J.T.Macaques as model hostsforstudiesof HIV-1 infection.Front.Microbiol.4,176(2013).

54. Wu, F. etal.TRIM5 $\alpha$ restriction affectsclinicaloutcomeand diseaseprogression in simian immunodeficiencyvirus-infected rhesusmacaques.J. Virol. 89,2233-2240(2015).

55. Lim,S.-Y.etal. TRIM5 $\alpha$ ModulatesImmunodeficiencyVirus Control inRhesusMonkeys. PLoS Pathog. 6,(2010).

56. Hatziioannou,T.etal. HIV-1-induced AIDS inmonkeys.Science344,1401-1405(2014).

57. Thippeshappa, R., Ruan, H.\&Kimata,J.T. BreakingBarrierstoan AIDSModelwithMacaqueTropic HIV-1Derivatives.Biology 1,134-164(2012).

58. Mascola, J. R.etal.Protectionofmacaquesagainstvaginal transmissionof apathogenicHIV1/SIV chimeric virusbypassiveinfusionof neutralizingantibodies.Nat.Med.6,207-210 (2000).

59. Rudicell,R. S. etal.Enhanced Potencyof aBroadlyNeutralizingHIV-1AntibodyInVitro ImprovesProtectionagainst Lentiviral InfectionInVivo.J. Virol. 88,12669-12682(2014).

60. Barouch,D. H. etal. Therapeutic EfficacyofPotentNeutralizingHIV-1-SpecificMonoclonal Antibodies in SHIV-InfectedRhesusMonkeys.Nature503,224-228(2013).

61. Shingai, M.etal. ANTIBODY MEDIATEDIMMUNOTHERAPYOF MACAQUESCHRONICALLY INFECTEDWITH SHIVSUPPRESSES VIREMIA.Nature503,277-280(2013).

62. Gengiah, T. N. etal. A drugevaluationof 1\%tenofovirgel andtenofovir disoproxilfumarate tablets forthe preventionof HIV infection.ExpertOpin. Investig. Drugs 21,695-715(2012).

63. Hessell, A. J.\&Haigwood,N. L. Animal Models in HIV-1 ProtectionandTherapy. Curr. Opin. HIVAIDS 10,170-176(2015).

64. Veazey,R. S.Animal Models forMicrobicideSafetyandEfficacyTesting.Curr. Opin. HIVAIDS 8,295-303(2013). 
65. Wilson, N.A.\&Watkins,D.I. Is an HIVVaccinePossible?Braz. J. Infect. Dis. Off.Publ.Braz. Soc. Infect. Dis.13, 304-310(2009).

66. Dezzutti, C.S. Animalandhumanmucosal tissuemodels to studyHIVbiomedical interventions:canwepredictsuccess?J. Int. AIDSSoc.18,(2015).

67. Hatziioannou,T. \&Evans,D. T. Animalmodels for HIV/AIDS research.Nat. Rev.Microbiol.10, 852-867(2012).

68. Policicchio,B. B.,Pandrea, I. \&Apetrei, C. Animal Models forHIV CureResearch.Front. Immunol. 7,(2016).

69. Passaes, C.P.\&Sáez-Cirión, A. HIVcureresearch:advancesandprospects. Virology454-455, 340-352(2014).

70. Saez-Cirion, A., Jacquelin, B., Barré-Sinoussi,F. \&Müller-Trutwin,M. Immuneresponses duringspontaneous control of HIV andAIDS: what is thehopefora cure?Philos.Trans. R. Soc. B Biol.Sci. 369,(2014).

71. Bruel, T. etal. Long-TermControlofSimianImmunodeficiencyVirus (SIV) inCynomolgus MacaquesNotAssociatedwith Efficient SIV-Specific CD8+T-CellResponses.J. Virol.89, 3542-3556(2015).

72. Kestler,H. W.etal.Importanceof thenef geneformaintenanceof highvirus loads andfor developmentof AIDS.Cel/65,651-662(1991).

73. Mothé, B.R. etal. ExpressionoftheMajor HistocompatibilityComplexClass I Molecule Mamu-A*01Is Associatedwith ControlofSimianImmunodeficiencyVirus SIVmac239 Replication. J. Virol.77,2736-2740(2003).

74. Nomura,T.\&Matano, T. AssociationofMHC-I genotypeswith diseaseprogressionin HIV/SIV infections.Front.Microbiol.3,(2012). 
75. Walter,L.\&Ansari, A. A.MHC andKIRPolymorphismsin RhesusMacaqueSIVInfection.

Front. Immunol. 6, 540(2015).

76. Albrecht, C.etal.ProgressiontoAIDSin SIV-InfectedRhesus MacaquesisAssociatedwith DistinctKIR andMHCclassI Polymorphisms andNKCell Dysfunction.Front. Immunol.5,600 (2014).

77. Santangelo,P. J.etal. Whole-bodyimmunoPETreveals activeSIV dynamicsinviremicand antiretroviraltherapy-treated macaques.Nat.Methods12,427-432(2015).

78. Whitney,J.B.etal. RapidSeedingofthe ViralReservoir Prior toSIVViremiain Rhesus Monkeys.Nature512,74-77(2014).

79. Sellier,P. etal. Antiretroviral Treatment Start-TimeduringPrimarySIVmac Infectionin MacaquesExertsaDifferentImpactonEarlyViral ReplicationandDissemination.PLOSONE 5,(2010).

80. Kader,M. etal. AntiretroviralTherapypriortoAcuteViralReplicationPreservesCD4TCells inthePeripherybutNotinRectalMucosa duringAcuteSimianImmunodeficiencyVirus Infection. J. Virol. 82, 11467-11471(2008).

81. Micci,L. etal. CD4Depletionin SIV-InfectedMacaquesResultsin MacrophageandMicroglia Infectionwith RapidTurnoverof InfectedCells.PLoSPathog.10,(2014).

82. Schmitz, J.E.etal.Controlof Viremia inSimianImmunodeficiencyVirus InfectionbyCD8+ Lymphocytes.Science283,857-860(1999).

83. Matano, T.etal. Administrationof an anti-CD8monoclonal antibodyinterfereswith the clearanceofchimericsimian/humanimmunodeficiency virusduringprimaryinfectionsof rhesus macaques.J. Virol.72,164-169(1998).

84. Jin, X. etal.DramaticRiseinPlasma Viremia afterCD8+TCellDepletionin Simian ImmunodeficiencyVirus-infectedMacaques.J. Exp. Med. 189,991-998(1999). 
85. O'Connor,D. H.etal. AcutephasecytotoxicTlymphocyteescapeisa hallmarkofsimian immunodeficiencyvirus infection.Nat. Med. 8,493-499(2002).

86. Reynolds,M. R.etal.CD8+T-LymphocyteResponsetoMajor ImmunodominantEpitopes afterVaginal ExposuretoSimianImmunodeficiencyVirus:TooLateandTooLittle.J. Virol. 79,9228-9235(2005).

87. Haase,A.T.EarlyEventsinSexualTransmissionof HIVandSIVandOpportunitiesfor Interventions.Annu. Rev.Med. 62,127-139(2011).

88. Choi, E. I.,Reimann, K.A. \&Letvin, N.L. InVivoNatural KillerCellDepletionduringPrimary SimianImmunodeficiencyVirus Infectionin RhesusMonkeys.J. Virol.82,6758-6761(2008).

89. Takahashi, Y.etal.InVivoAdministrationof aJAK3Inhibitor toChronicallySIVInfected Rhesus MacaquesLeadstoNKCellDepletionAssociated withTransientModestIncreasein ViralLoads.PLoSONE8,(2013).

90. Keele, B. F. etal. IncreasedmortalityandAIDS-likeimmunopathologyinwildchimpanzees infectedwith SIVcpz.Nature460,515-519(2009).

91. Etienne,L.etal. Characterizationof anewsimianimmunodeficiencyvirus strainina naturallyinfectedPantroglodytestroglodyteschimpanzee withAIDS relatedsymptoms. Retrovirology8,4(2011).

92. Sodora,D.L.etal. TowardanAIDS vaccine:lessons fromnaturalsimianimmunodeficiency virus infectionsof Africannonhumanprimatehosts.Nat. Med.15,861-865(2009).

93. Chahroudi, A., Bosinger,S.E., Vanderford,T. H.,Paiardini, M. \&Silvestri, G. Natural SIV Hosts:ShowingAIDStheDoor.Science335,(2012).

94. Kornfeld,C.etal. AntiinflammatoryprofilesduringprimarySIVinfectionin Africangreen monkeys areassociated with protectionagainstAIDS.J. Clin. Invest. 115,1082-1091(2005). 
95. Chakrabarti,L. A. etal. Normal T-CellTurnoverinSooty Mangabeys HarboringActiveSimian ImmunodeficiencyVirusInfection.J. Virol.74,1209-1223(2000).

96. Rotger, M.etal. Comparativetranscriptomicsof extremephenotypesof humanHIV-1 infectionandSIVinfectioninsootymangabeyandrhesus macaque.J. Clin. Invest.121,23912400(2011).

97. Kirchhoff, F.Isthehighvirulenceof HIV-1an unfortunatecoincidenceof primatelentiviral evolution?Nat. Rev.Microbiol.7,467-476(2009).

98. Estes,J.D.etal.Damaged Intestinal Epithelial Integrity Linked toMicrobial Translocationin PathogenicSimianImmunodeficiencyVirus Infections.PLoSPathog.6,(2010).

99. Pandrea, I.etal. CuttingEdge:ExperimentallyInducedlmmuneActivationin NaturalHostsof SimianImmunodeficiencyVirus InducesSignificantIncreasesin ViralReplicationandCD4+T Cell Depletion.J. Immunol. Baltim. Md1950 181, 6687-6691(2008).

100. Breed,M. W.etal.Lossofa Tyrosine-DependentTrafficking Motif inthe Simian ImmunodeficiencyVirusEnvelopeCytoplasmicTailSparesMucosal CD4Cells butDoesNot PreventDiseaseProgression.J. Virol. 87,1528-1543(2013).

101.Jacquelin, B. etal. NonpathogenicSIV infectionofAfricangreenmonkeys induces astrong but rapidlycontrolled typel IFNresponse.J. Clin. Invest.119,3544-3555(2009).

102. Jochems, S.P.etal. Plasmacytoid DendriticCellInfectionandSensingCapacityduring PathogenicandNonpathogenicSimianImmunodeficiencyVirus Infection.J. Virol.89,6918$6927(2015)$

103. Schindler, M. etal.Nef-Mediated SuppressionofTCell ActivationWasLostinaLentiviral Lineagethat GaveRisetoHIV-1.Cel/125,1055-1067(2006).

104. Paiardini, M.etal.Lowlevels ofSIVinfectionin sootymangabeycentral-memoryCD4+T- cellsis associatedwith limitedCCR5expression.Nat.Med. 17,830-836(2011). 
105. Veazey,R.etal. DecreasedCCR5ExpressiononCD4+TCellsof SIV-Infected Sooty Mangabeys.AIDSRes. Hum. Retroviruses 19,227-233(2003).

106. Pandrea, I.etal.PaucityofCD4+CCR5+TCellsMayPreventTransmissionof Simian ImmunodeficiencyVirusinNatural NonhumanPrimateHostsbyBreast-Feeding.J. Virol. 82, $5501-5509(2008)$.

107. Ploquin,M. J., Silvestri,G.\& Müller-Trutwin,M. Immuneactivationin HIVinfection:what can the natural hostsofsimianimmunodeficiencyvirusteachus?Curr. Opin. HIVAIDS11,201208(2016).

108. Gueye,A. etal. Viralloadintissuesduringtheearlyandchronic phaseofnon-pathogenic SIVagminfection.J.Med. Primatol.33,83-97(2004).

109. Martinot,A.J. etal.AcuteSIV InfectioninSooty MangabeyMonkeysls Characterized by RapidVirus ClearancefromLymphNodesandAbsence ofProductivelnfectioninGerminal Centers.PLOSONE8,(2013).

110. Brenchley,J.M.etal.Differentialinfectionpatternsof CD4+Tcellsandlymphoidtissueviral burden distinguishprogressiveandnonprogressivelentiviral infections. Blood 120,41724181(2012).

111. Diop,O.M.etal. HighLevels of ViralReplicationduringPrimarySimianImmunodeficiency Virus SIVagmInfectionAreRapidlyandStronglyControlled inAfricanGreen Monkeys.J. Virol. 74,7538-7547(2000).

112. Goldstein,S.etal.WideRange of ViralLoadin HealthyAfricanGreen MonkeysNaturally Infectedwith SimianImmunodeficiencyVirus.J. Virol.74,11744-11753(2000).

113. Beer, B.etal.Lackofdichotomybetweenvirus loadofperipheral bloodandlymphnodes duringlong-termsimianimmunodeficiencyvirusinfectionof Africangreenmonkeys. Virology219,367-375(1996). 
114. Ploquin,M. J.-Y., Jacquelin,B., Jochems, S.P., Barré-Sinoussi, F.\&Müller-Trutwin, M. C. Innateimmunityin the controlof HIV/AIDS:recent advancesandopenquestions.AIDSLond. Engl. 26,1269-1279(2012).

115. Ploquin,M. J.-Y.etal. DC-SIGNfromAfricanGreenMonkeys Is ExpressedinLymphNodes andMediatesInfectionintrans of SimianImmunodeficiencyVirusSIVagm.J. Virol.78,798810(2004).

116. Cumont,M.-C. etal.EarlyDivergencein LymphoidTissue Apoptosis betweenPathogenicand NonpathogenicSimianImmunodeficiencyVirus Infectionsof NonhumanPrimates.J. Virol. 82,1175-1184(2008).

117. Hurtrel,B. etal. Apoptosis inSIVinfection. CellDeathDiffer.12,979-990(2005).

118. Elder,J. H., Lin,Y.-C., Fink,E. \&Grant,C.K. FelinelmmunodeficiencyVirus (FIV)as A Model for StudyofLentivirus Infections:Parallelswith HIV.Curr. HIVRes.8,73-80(2010).

119. Mohammadi, H.\&Bienzle,D. Pharmacological InhibitionofFelinelmmunodeficiencyVirus (FIV). Viruses4,708-724(2012).

120. Denton,P. W.\&Garcia, J.V.Humanized MouseModels ofHIV Infection.AIDSRev.13,135148(2011).

121. Garcia, J.V. Invivoplatforms for analysisof HIV persistenceanderadication.J. Clin. Invest. $126,424-431(2016)$.

122. Legrand, N. etal. Humanized miceformodelinghumaninfectious disease:challenges, progress,andoutlook.CellHost Microbe6,5-9(2009).

123. Seung, E.etal.PD-1BlockadeinChronicallyHIV-1-InfectedHumanized MiceSuppressesViral Loads.PLOSONE8,(2013). 
124. Kovarova,M.etal.A long-actingformulationof theintegraseinhibitor raltegravir protects humanized BLTmicefromrepeatedhigh-dosevaginalHIVchallenges.J. Antimicrob. Chemother. dkw042(2016). doi:10.1093/jac/dkw042

125. Olesen,R., Wahl,A., Denton, P. W.\&Garcia,J. V.ImmuneReconstitutionof theFemale ReproductiveTract ofHumanized BLTMiceandtheirSusceptibilitytoHuman ImmunodeficiencyVirusInfection.J. Reprod.Immunol.88,195-203(2011).

126. Sundell,I.B., Cortado,R.V.\&Koka,P. S.Sulfatide--a newcandidatefor ARTtreatmentin HIV-1infection.J. StemCells7,61-72(2012).

127. Honeycutt,J. B.etal. MacrophagessustainHIV replicationinvivoindependentlyof Tcells.J. Clin. Invest. 126,1353-1366(2016).

128. Miller,C.J. etal. Genitalmucosal transmissionof simianimmunodeficiencyvirus:animal model for heterosexualtransmissionofhumanimmunodeficiencyvirus.J. Virol.63,42774284(1989).

129. Veazey,R.S., Shattock,R. J., Klasse,P.J.\&Moore,J. P. Animalmodels formicrobicide studies. Curr.HIVRes.10,79-87(2012).

130. Bernard-Stoecklin, S.,Gommet, C., Cavarelli, M.\&Grand, R. L. NonhumanPrimateModels for Cell-AssociatedSimianImmunodeficiencyVirus Transmission:TheNeed toBetter UnderstandtheComplexity ofHIV MucosalTransmission.J. Infect. Dis.210,S660-S666 (2014).

131. Bernard-Stoecklin, S.etal.SemenCD4+TCells andMacrophagesAreProductivelyInfected atAll StagesofSIVinfectionin Macaques. PLoSPathog.9,(2013).

132. Pandrea, I.etal.Mucosal SimianImmunodeficiencyVirus TransmissioninAfricanGreen Monkeys:SusceptibilitytoInfectionls Proportional toTargetCellAvailabilityatMucosal Sites. J. Virol.86,4158-4168(2012). 
133. Chahroudi, A. etal.Mother-to-InfantTransmissionofSimianImmunodeficiencyVirus IsRare

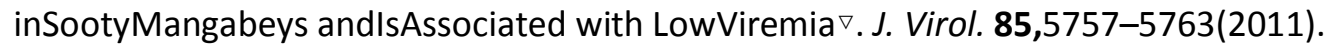

134. Ma,D. etal. Factors Associatedwith SimanImmunodeficiencyVirus Transmissionin a Natural AfricanNonhumanPrimateHostin theWild. J.Virol. 88,5687-5705(2014).

135. Marlin, R.etal.Decidual soluble factors participateinthe control ofHIV-1infectionatthe maternofetal interface. Retrovirology8,58(2011).

136. Tripathi, V. etal. Differential expressionof RDC1/CXCR7in thehumanplacenta.J. Clin. Immunol. 29,379-386(2009).

137. Veazey,R.S. etal. IdentifyingtheTargetCellinPrimarySimianImmunodeficiencyVirus (SIV) Infection:HighlyActivatedMemoryCD4+TCellsAre RapidlyEliminatedin Early SIV Infection InVivo. J. Virol. 74, 57-64(2000).

138. Li, Q.etal. Glycerolmonolauratepreventsmucosal SIV transmission.Nature458,1034-1038 (2009).

139. Reimann,K. A. etal.Immunopathogeniceventsin acuteinfectionof rhesusmonkeyswith simianimmunodeficiency virus ofmacaques.J. Virol.68,2362-2370(1994).

140. Letvin, N.L.etal. CytotoxicTlymphocytesspecificforthe simianimmunodeficiencyvirus. Immunol. Rev.170, 127-134(1999).

141. Barouch,D. H. etal. Protectiveefficacyof adenovirus/proteinvaccinesagainstSIVchallenges inrhesusmonkeys.Science349,320-324(2015).

142. Reeves, R.K.,Evans, T. I., Gillis, J.\&Johnson, R.P. SimianImmunodeficiencyVirusInfection InducesExpansion of $\alpha 4 \beta 7+$ andCytotoxicCD56+NKCells.J. Virol.84,8959-8963(2010).

143. Reeves,R.K.etal.CD16- natural killercells: enrichmentinmucosalandsecondarylymphoid tissues andalteredfunctionduringchronic SIV infection.Blood115,4439-4446(2010). 
144. Reeves,R.K.etal.SIV InfectionInducesAccumulationofPlasmacytoidDendriticCells inthe Gut Mucosa.J. Infect.Dis.206,1462-1468(2012).

145. Picker, L.J. etal. Insufficient productionandtissue delivery ofCD4+memoryTcells in rapidly progressivesimianimmunodeficiencyvirus infection.J. Exp. Med.200,1299-1314(2004).

146. Monaco,C. L.etal.AlteredViromeandBacterial Microbiomein HumanImmunodeficiency VirusAssociated Acquired ImmunodeficiencySyndrome.Cell HostMicrobe19,311-322 (2016).

147. Palmer,B.E.,Li, S.X.\&Lozupone,C. A.TheHIV-Associated EntericMicrobiomeHas Gone Viral. Cell HostMicrobe 19,270-272(2016).

148. Barbian, H.J. etal.Destabilizationof thegutmicrobiomemarkstheend-stageofsimian immunodeficiency virus infectionin wildchimpanzees.Am. J. Primatol.(2015). doi:10.1002/ajp.22515

149. Handley, S. A. etal.SIV Infection-MediatedChangesinGastrointestinalBacterialMicrobiome andViromeAreAssociated with ImmunodeficiencyandPrevented byVaccination. Cell Host Microbe19,323-335(2016).

150. Namikawa,R.,Kaneshima,H., Lieberman,M.,Weissman, I. L. \&McCune,J.M. Infectionof the SCID-huMousebyHIV-1. Science(1988).

151. Choudhary,S.K.etal.LatentHIV-1InfectionofRestingCD4+TCellsintheHumanized

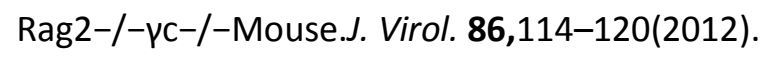

152. Wege,A.K.,Melkus, M.W., Denton,P.W., Estes, J.D.\&Garcia,J.V. Functionaland phenotypiccharacterizationof thehumanizedBLTmousemodel.Curr. Top.Microbiol. Immunol. 324,149-165(2008).

153. Denton,P. W.etal.AntiretroviralPre-exposureProphylaxisPrevents Vaginal Transmissionof HIV-1in Humanized BLTMice.PLoSMed.5,(2008). 
154. Karpel,M. E., Boutwell,C. L. \&Allen,T. M.BLThumanized miceasa small animalmodelof HIVinfection. Curr.Opin. Virol.13,75-80(2015).

155. Shytaj,I.L.etal. AHighlyIntensified ARTRegimen InducesLong-TermViralSuppressionand Restrictionofthe ViralReservoir inaSimianAIDS Model.PLoSPathog.8,(2012).

156. DelPrete,G. Q. etal.ShortCommunication:ComparativeEvaluationof Coformulated InjectableCombinationAntiretroviralTherapyRegimens in SimianImmunodeficiencyVirusInfected RhesusMacaques.AIDSRes. Hum. Retroviruses32,163-168(2016).

157. Vassena,L. etal.Treatmentwith IL-7PreventstheDecline ofCirculatingCD4+TCells during the AcutePhaseof SIVInfectioninRhesusMacaques.PLoSPathog.8,(2012).

158. Xu, H., Wang,X. \& Veazey,R. S.Th17Cells Coordinatewith Th22Cells inMaintaining Homeostasisof Intestinal Tissuesandboth areDepleted inSIV-InfectedMacaques.J. AIDS Clin. Res. 5,(2014).

159. Ling, B.etal. Effectsof Treatment with SuppressiveCombinationAntiretroviralDrugTherapy andtheHistoneDeacetylaseInhibitor SuberoylanilideHydroxamicAcid; (SAHA)onSIVInfected ChineseRhesus Macaques.PLoSONE9,(2014).

160. DelPrete,G. Q.etal.Effectof SuberoylanilideHydroxamic Acid(SAHA) Administrationon the Residual Virus Pool inaModelof CombinationAntiretroviralTherapy-Mediated Suppressionin SIVmac239-Infected IndianRhesusMacaques.Antimicrob. AgentsChemother.

$58,6790-6806(2014)$.

161. Trautmann,L. Kill:boostingHIV-specificimmuneresponses. Curr. Opin. HIVAIDS(2016).doi:10.1097/COH.0000000000000286

162. Datta,P.K.etal. HIV-1LatencyandEradication:Past,Present andFuture. Curr. HIVRes. (2016). 
163. Wen, J. etal. SpecificEliminationof LatentlyHIV-1InfectedCells UsingHIV-1 ProteaseSensitiveToxin Nanocapsules.PloSOne11,e0151572(2016). 
Figure 1

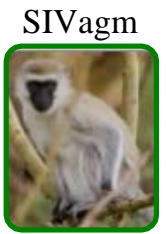

Chlorocebussabaeus

Chlorocebuspygerythrus

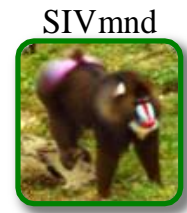

Mandrillussphinx

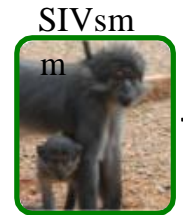

Cercocebusatys $^{93}$
Pantroglodytestroglodytes Pantroglodytesschweinfurthii
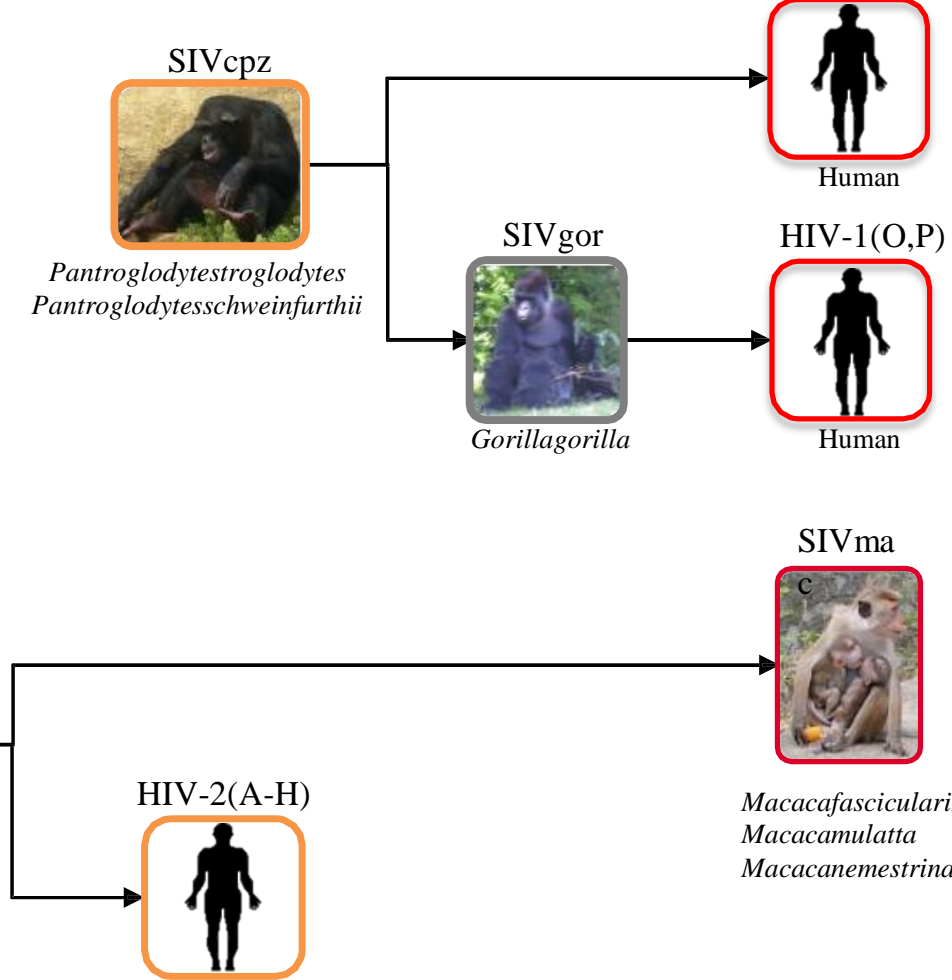

Macacafascicularis Macacamulatta

Macacanemestrina

Human

Slowprogression 

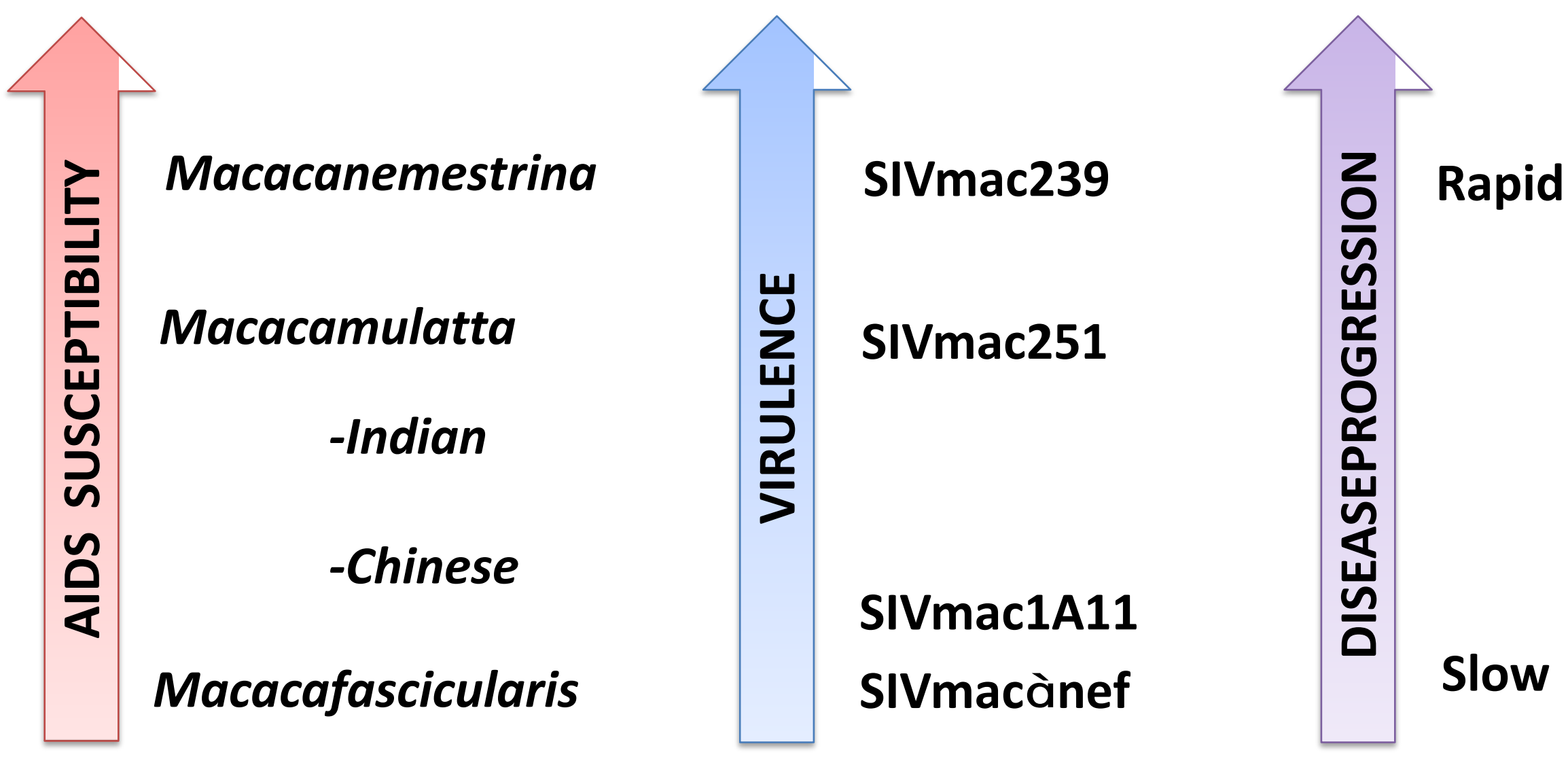

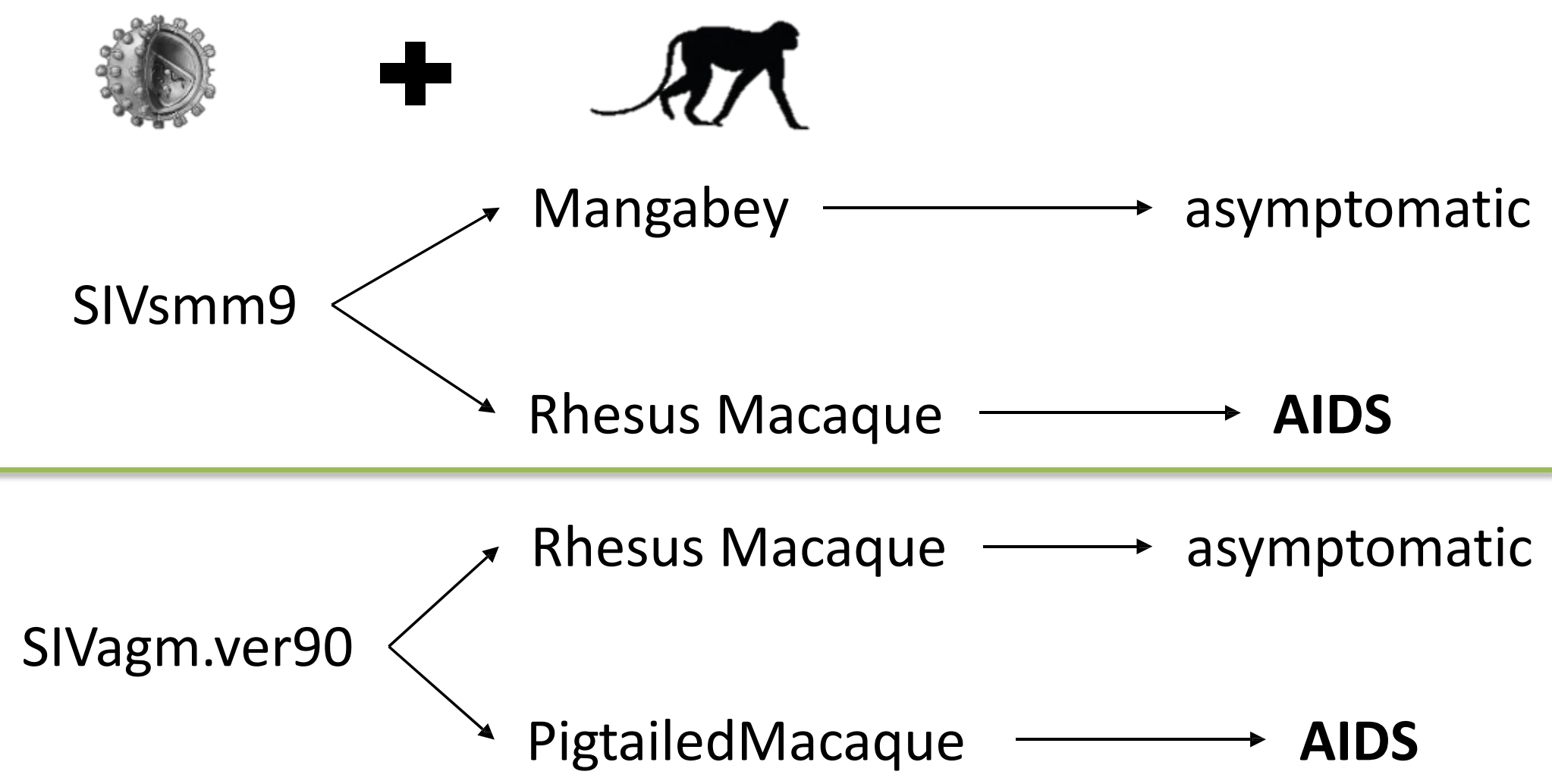

SIVagm.ver155 $\longrightarrow$ PigtailedMacaque $\longrightarrow$ asymptomatic 


\section{Captions}

Figure1.Non-human primate models for thestudy ofHIV infection.Non-human primates can bedivided into pathogenic (macaques) and non-pathogenic (sootymangabeys, mandrills and African Green Monkeys) models for HIV research. The figuredepicts the relationship between theHIV and SIV viruses andthe typeof infectioncaused bythem.

Figure2. Host andviraldeterminants of diseaseprogressionrate. Theprogression ofthe diseasedepends on theintrinsic susceptibilityof each species to develop AIDSand on the virulenceof theSIV strain used.

Figure3Cross-species transmissions ofSIV and fates ofinfection. Thepresenceor absenceof progression depends on both, viral andhost factors; i.e. the infection with a given SIV strain will notcausediseasein some primates, whereas in others willlead to the development of AIDS.Host and viral determinants interact whicheach other and a combination ofboth determines the outcome ofinfection. 